University of Rhode Island

DigitalCommons@URI

The Rhode Island Current Conditions Index

Economics

$12-2015$

\title{
Rhode Island Current Conditions Index - December 2015
}

Leonard Lardaro

University of Rhode Island, lardaro@uri.edu

Follow this and additional works at: https://digitalcommons.uri.edu/ricci

Part of the Econometrics Commons

Terms of Use

All rights reserved under copyright.

\section{Recommended Citation}

Lardaro, Leonard, "Rhode Island Current Conditions Index -- December 2015" (2015). The Rhode Island Current Conditions Index. Paper 144.

https://digitalcommons.uri.edu/ricci/144

This Article is brought to you for free and open access by the Economics at DigitalCommons@URI. It has been accepted for inclusion in The Rhode Island Current Conditions Index by an authorized administrator of DigitalCommons@URI.For more information, please contact digitalcommons-group@uri.edu. 


\title{
CURRENT CONDITIONS
}

LEONARD LARDARO, URI

\author{
Available Online: http:/ / www .Ilardaro.com/ current.htm \\ Blog: http:/ / rieconomy.blogspot.com \\ Twitter: @ladardo
}

VOL XXIHI

NUMBER 1

DEC 2015
It wasn't too hard to see what December would bring for Rhode Island's economy: like the nation, Rhode Island slowed a bit further, as weakness in our goods-producing sector continued becoming a bit worse than was the case in November. Ironically, almost everyone here overlooked this entirely and instead chose to celebrate the decline in our state's jobless rate to 5.1 percent, presuming as they so often do that the Unemployment Rate by itself is a sufficient basis with which to characterize our state's economic performance. Obviously, that presumption is false for two reasons. First, while our jobless rate was at its lowest value in many years, recent rates are not comparable to rates in earlier years since at present, participation rates are much lower than they were back then. Perhaps more importantly, to accurately assess economic performance, it is necessary to evaluate the performance of a broadly based set of indicators, which is precisely what the Current Conditions Index does.

For December, the Current Conditions Index fell from its November value of 75 all the way back to 58 , its level in April and a continuation of its downward trajectory from the August high of 92, as only seven of the twelve $\mathrm{CCl}$ indicators improved.

\begin{tabular}{|l|r|r|}
\hline \multicolumn{3}{|c|}{ CCI Indicators - \% Change } \\
\hline Government Employment & -1.3 \\
\hline US Consumer Sentiment & -1.0 \\
\hline Single-Unit Permits & -11.5 & \\
\hline Retail Sales & 5.5 & Y \\
\hline Employment Services Jobs & 5.1 & Y \\
\hline Priv. Serv-Prod Employment & 2.4 & Y \\
\hline Total Manufacturing Hours & -2.9 & \\
\hline Manufacturing Wage & -3.3 & \\
\hline Labor Force & 1.1 & Y \\
\hline Benefit Exhaustions & -32.7 & Y \\
\hline New Claims & -13.3 & Y \\
\hline Unemployment Rate (change) & -1.7 & Y \\
\hline \multicolumn{2}{|c|}{ Y = Improved Value } \\
\hline
\end{tabular}

In a sign of what we might see more frequently going into 2016 , the $\mathrm{CCl}$ this month failed to beat its level from a year ago, ending a streak of nine consecutive months for which we had either matched or exceeded year-earlier values.

There was some good news for December. The weakness in the $\mathrm{CCl}$ value largely reflected that fact that overall, our negatives grew relative to our positives. This should not come as a total surprise, however, given the slowdown in growth nationally. As has been true for several months now, much of our recent weakness continues to be concentrated in our state's goodsproducing sector, in manufacturing and new home construction.

Total Manufacturing Hours, a measure of manufacturing sector strength, fell by 2.9 percent in December, its seventh decline in the last nine months and its worst decline in well over year. Along with this, the Manufacturing Wage declined yet again, this month by 3.3 percent. New home construction, in terms of Single-Unit Permits, fell by 11.5 percent in December, partly the result of a difficult comp a year ago. This follows a bizarre increase of 58.6 percent in November. I still don't understand what is happening with this indicator. US Consumer Sentiment fell for the first time in fifteen months $(-1.0 \%)$.

Among December's seven improving indicators were only two of the CCl's five leading indicators. Employment Service Jobs, which includes temporary employment and is a prerequisite to employment growth, rose by 5.1 percent, among its highest growth rates in quite some time. This indicator has clearly strengthened since June. Finally, New Claims, a leading labor market indicator that reflects layoffs, fell by 13.3 percent in December, assisted by a very easy comp one year ago.

Retail Sales growth reaccelerated in December $(+5.5 \%)$ making this its nineteenth consecutive improvement. Private Service-Producing Employment, one of the indicators whose monthly growth has not slowed of late, rose by another 2.4 percent in December. Government Employment fell again (-1.3\%). Benefit Exhaustions, which reflects longer-term unemployment, declined by 32.7 percent relative to last year. While our Labor Force managed to sustain its recent uptrend on a yearly but not monthly basis $(+1.1 \%)$, it fell back to its April level. Because of this, my major concern moving forward continues to be the declines in both our employment rate and labor force participation rate that began in July. Both remain well below their recession levels. So, once again, Rhode Island finds its Unemployment Rate falling for the wrong reasons. Any comparison of the current and 2007 jobless rates is purely spurious.
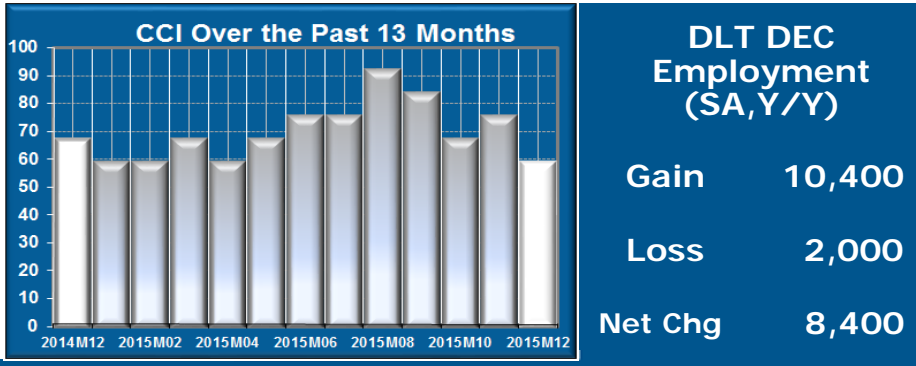

\section{THE BOTTOM LINE}

Rhode Island ended the year on a bitter sweet note, as the Current Conditions Index fell back to 58, its level in April, and a continuation of the slowing of growth that began in August. I ronically, most people here continue to think that our state's growth rate is accelerating, based on an inappropriately focused view that the Unemployment Rate tells us all we need to know about our state's rate of growth. While payroll employment growth here has accelerated of late, we need to see if this is confirmed by the rebenchmarked labor market data that will be released shortly. Even if it is, we will still be 20 percent below our prior employment peak of December of 2006.

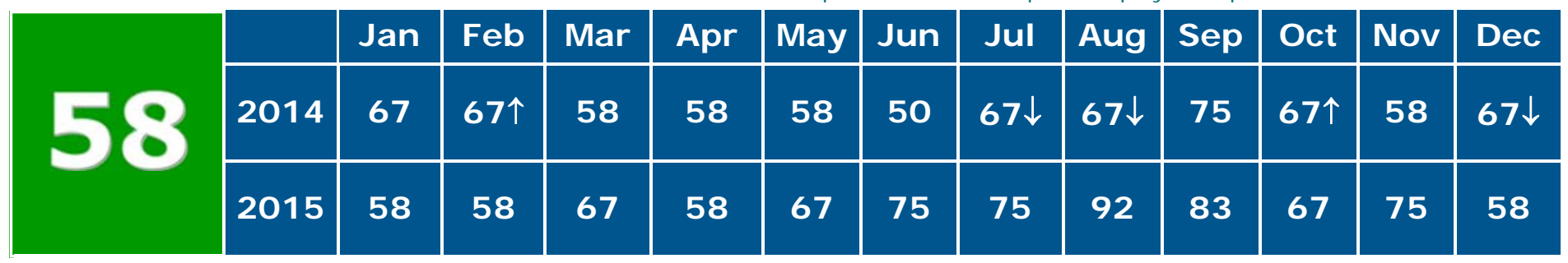

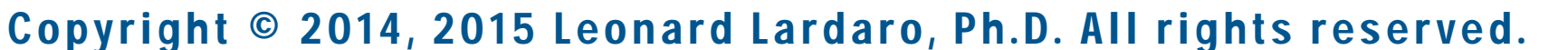

